\title{
Plasma deposition of antimicrobial coatings based on silver and copper on polypropylene
}

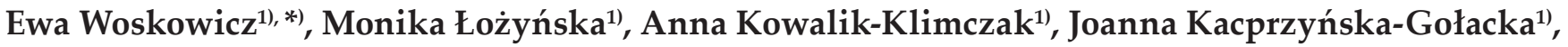 \\ Edyta Osuch-Słomka ${ }^{1)}$, Artur Piasek ${ }^{1)}$, Leon Gradońn ${ }^{2)}$
}

DOI: dx.doi.org/10.14314/polimery.2020.1.5

\begin{abstract}
This paper addresses the issue of plasma treatment of the surface of polypropylene (PP) using sputtering of silver $(\mathrm{Ag})$ and copper $(\mathrm{Cu})$ and their oxides with MS-PVD in order to impart antimicrobial activity. It was found that plasma treatment of PP with $\mathrm{Cu}$ and $\mathrm{Ag}$ based layers allows to provide excellent antimicrobial properties due to a constant release of metal ions. The samples of PP treated with $\mathrm{Cu}$ and $\mathrm{CuO}$ were characterized by highest antimicrobial properties and stability of the coatings. The most stable and least effective coating against bacteria was Ag-PP sample. In turn, AgO-PP was characterized by the lowest stability in aqueous conditions and strong antimicrobial activity. It was found that leaching of metal ions from the surface of treated PP even in exceptional levels plays a crucial role in bactericidal activity.
\end{abstract}

Keywords: polypropylene, plasma treatment, silver, copper, antibacterial properties.

\section{Plazmowa depozycja antybakteryjnych powłok srebra i miedzi na powierzchni polipropylenu}

\begin{abstract}
Streszczenie: Niniejsza praca dotyczy plazmowej obróbki powierzchni polipropylenu (PP) przy użyciu miedzi $(\mathrm{Cu})$ i srebra $(\mathrm{Ag})$ oraz ich tlenków. Powłoki $\mathrm{Cu}, \mathrm{CuO}, \mathrm{Ag}$ i $\mathrm{AgO}$, wytworzone na powierzchni PP metodą rozpylania magnetronowego MS-PVD, zbadano pod względem morfologii, składu, stabilności i właściwości antybakteryjnych. Materiały powierzchniowo zmodyfikowane przy użyciu $\mathrm{Cu}$ i CuO charakteryzowały się najsilniejszymi właściwościami przeciwbakteryjnymi i najmniejszą stabilnością i trwałością w środowisku wodnym. Powłoka $\mathrm{AgO}$ wykazywała najmniejszą stabilność w warunkach wodnych i silną aktywność przeciwbakteryjną, natomiast powłoka Ag wykazywała największą stabilność, a zarazem najsłabsze działanie przeciwbakteryjne. Uzyskane wyniki wskazują, że uwalniane z naniesionych powłok jony, nawet w niewielkim stężeniu, wykazują silne działanie antybakteryjne.
\end{abstract}

Słowa kluczowe: polipropylen, obróbka plazmowa, srebro, miedź, właściwości antybakteryjne.

In the industry synthetic polymers pose the crucial production components of many materials, which are versatile in the manufacturing of all kinds of goods in packaging, medicine, filtration materials, construction elements, piping systems, etc. [1-3]. Although, the detrimental impact of polymers on environment is well-known and confirmed, they have been found to expand the area of application for almost all fields of human activity due to the low cost, ease of processing and good mechanical properties [3]. Since materials made of polymers are generally non-toxic and chemically passive, in many cases they can

\footnotetext{
1) ŁUKASIEWICZ Research Network-Institute for Sustainable Technologies (ŁUKASIEWICZ-ITEE), Pułaskiego 6/10, 26-600 Radom, Poland.

2) Warsaw University of Technology, Faculty of Chemical and Process Engineering, Waryńskiego 1, 00-645 Warsaw, Poland.

*) Author for correspondence;

e-mail: ewa.woskowicz@itee.radom.pl
}

be easily exposed to biofouling resulting in biofilm formation on their surfaces. Some polymer materials used for the manufacturing of a wide range of products available in the industry, e.g. textiles, food packaging, biomedical devices or piping systems, can be particularly susceptible for microbial growth on their surfaces. To survive in fluctuating conditions, microbes have evolved the mechanisms of the surface attachment and living in a community. Microbial biofilms are dense, structured aggregates, where microbes are strongly bound to the colonized surface of materials and other microbial cells in surrounding environment $[4,5]$. They may form on both living or non-living surfaces and are prevalent in natural, industrial and hospital settings [6]. Biofilm appearance greatly affects industrial processes, deteriorates materials quality, limits the hygiene maintenance, causes malfunctions of devices or the increase in material and energy consumption. These lead to the reduction in the efficiency of the technology, causes the need to clean the installation com- 
ponents with strong chemical biocides [7]. Due to the high intensity of microbial pollutants on surfaces of elements during operation, the lifetime of material is significantly shortened and impaired. Therefore, the ability to resist biofouling and contributing factors are of a great significance. The common application of polymers involves manufacturing of fibrous filtration materials and membranes as well as filtration plant construction elements. The phenomenon of biofouling formation is particularly unnecessary during filtration processes as it decreases filtration and separation performance and greatly increases operating costs [8-10]. Thus, there is an increasing need to search for an appropriate method of reducing biofouling by modifications of materials coming into contact with pathogens. Recently, various methods of modification of applied materials have been extensively studied to overcome the problem of microbes forming biofilms on the surfaces of polymer materials [10,11]. This was especially examined for materials made of polymers such as wound dressings, cotton fibres, artificial anti-inflammatory blood vessels, and many others [12-14]. Strategies used to functionalize polymer materials involve either embedding antimicrobial agents in the form of metals or their oxides into the polymer matrix or incorporation on polymer surfaces [11-16]. The functionalization of the surface is more accessible and likely to improve surface properties of final completed products made of polymers. The main aims of surface modifications are to alter several properties such as wettability, chemical inertness, cross-linking of the surface, boundary layers and impurities, surface morphology, electrical conductivity [17]. The modifications routes for imparting antimicrobial properties mainly involve incorporation of metals or their oxides especially in the form of nanoparticles. Antibacterial agents widely described in the literature are compounds containing silver and copper $[15,18]$. They have already found numerous applications in water treatment, healthcare, and the industry in general since they can be toxic to wide range of microorganisms such as bacteria, algae or fungi at very exceptional levels. Compounds of copper belong to the relatively small groups of biocides that are safe to human health [19]. By testing a set of metal surfaces, it was shown that those containing copper and silver are the most effective in reducing bacterial viability [20, 21]. Today these metal based additives are found in the form of particles, ions absorbed/exchanged in different carriers, polymer matrix, etc. One recent and novel direction to further extend antimicrobial applications of these compounds and create new functional properties to materials is plasma deposition of thin layers of metals or their oxides on the surface of polymers [11, 22, 23]. Especially, the use of low temperature plasma seems the most universal method of surface modification of polymers, and its rapid development has been observed in the last years. This is particularly because plasma techniques are fast, clean and ecological [24-27]. Plasma is partially ionized gas (or a mixture of gases) consisting of equal number of electrons, ions and atoms, inert molecules and electromagnetic radiation resulted from a discharges occurred in vacuum chamber. Materials subjected to plasma treatment show changes in the properties of the surface and in the chemical structure of the surface layer resulting in higher durability of an adhesive metallic coating due to its strong anchoring on the surface [17]. From a practical point of view, the stability of the functional metallic coatings deposited on the surface of polymers is an important aspects, particularly when the materials come into contact with liquids, as high levels of metal ions leached from the surface can be undesirable effect in some cases leading to serious consequences which are manifested by the pigmentation of the skin, breathing problems, allergic reactions in human body when exposed to excessive absorption of silver compounds (most commonly in the form of silver or colloidal dust) [28].

The aim of the work was to deposit thin layers of coatings based on silver $(\mathrm{Ag}, \mathrm{AgO})$ and copper $(\mathrm{Cu}, \mathrm{CuO})$ onto the surface of polypropylene using magnetron sputteringphysical vapour deposition method (MS-PVD) and examining their stability in aqueous solution and antibacterial efficiency against both Gram-positive (Staphylococcus aureus) and Gram-negative bacteria (Escherichia coli) in static and dynamic contact conditions. Furthermore, the other properties were investigated such as wettability, morphology and chemical composition of plasma treated polypropylene materials.

\section{EXPERIMENTAL PART}

\section{Materials}

Polymer materials selected to plasma treatment with MS-PVD method were raw polypropylene (PP) samples outsourced and prepared as a discs of a diameter of $2.54 \mathrm{~cm}$ cut with a plotter from the $5 \mathrm{~mm}$ thick panel. The geometry of the samples were dictated by the holders in a plasma vaccum reactor built by the ŁUKASIEWICZ Research Network-Institute for Sustainable Technologies (ŁUKASIEWICZ-ITEE). All reagents were analytical grade. Millipore-quality water was used for all solution preparations. Microbiological reagents such as Luria-Bertani broth (LB), Luria-Bertani Miller Agar (LBA) were supplied by VWR Chemicals. Chemical reagents to prepare saline buffers were purchased from Chempur.

\section{Plasma coating deposition}

Prior to plasma treatment, the polypropylene discs were washed with $96 \%$ ethanol in an ultrasonic bath for $10 \mathrm{~min}$ and dried. The surface of prepared PP samples were coated with metallic $(\mathrm{Ag}, \mathrm{Cu}$ ) layers with MS-PVD. The coatings consisting of $\mathrm{AgO}$ and $\mathrm{CuO}$ were obtained with both metallic and gaseous low temperature plasma in vaccum chamber constructed by ŁUKASIEWICZ-ITEE. This device is equipped with three circular magnetrons 
T a b l e 1. Parameters of MS-PVD process used to treat polypropylene

\begin{tabular}{c|c|c|c|c}
\hline \multirow{2}{*}{ Parameters } & \multicolumn{4}{|c}{ Coating } \\
\cline { 2 - 5 } & $\mathrm{Cu}$ & $\mathrm{CuO}$ & $\mathrm{Ag}$ & $\mathrm{AgO}$ \\
\hline Target & $\mathrm{Cu}$ & $\mathrm{Cu}$ & $\mathrm{Ag}$ & $\mathrm{Ag}$ \\
Sputtering & $100 \% \mathrm{Ar}$ & $90 \% \mathrm{Ar}$ & $100 \% \mathrm{Ar}$ & $90 \% \mathrm{Ar}$ \\
gas & & $10 \% \mathrm{O}_{2}$ & & $10 \% \mathrm{O}_{2}$ \\
Time, min & 30 & 20 & 10 & 6.5 \\
\hline
\end{tabular}

located on three opposite sides of the chamber. The magnetrons were equipped with disc targets with a diameter of $\varnothing=140 \mathrm{~mm}$ and a thickness of $g=7 \mathrm{~mm}$. The intensity of magnetron and the pressure in the vaccum chamber were constant and equal to $0.8 \mathrm{~A}$ and $0.5 \mathrm{~Pa}$, respectively. An appropriate time was selected to obtain thickness of layers equal to $650 \mathrm{~nm}$. The parameters of MS-PVD process used to treat PP samples were presented in Table 1. The thickness of obtained coatings were measured with scanning electron microscope (SEM) Hitachi TM 3000.

\section{Methods of testing}

\section{Contact angle}

Wettability of plasma treated surface of solid PP (before and after treatment) was examined through the changes of the contact angle for demineralized water $\left(\mathrm{dH}_{2} \mathrm{O}\right)$ using the static sessile drop method. The drop of $\mathrm{dH}_{2} \mathrm{O}$ in a constant volume of $2 \mathrm{~mm}^{3}$ was poured on the surface of PP using Hamilton microsyringe. The static contact angle values were automatically measured by goniometer constructed by ŁUKASIEWICZ-ITEE. For each polymer sample, 10 measurements of contact angles were taken. For each series of measurements, a Dixon's $Q$ test was performed to reject outliers. The mean value was calculated from 8 measurements and variability of the results characterized by the standard deviation.

\section{Stability of PVD-coatings}

The stability of coatings deposited on the polypropylene surface with MS-PVD was examined through the measurements of leached metals (ions) into $\mathrm{dH}_{2} \mathrm{O}$ from the treated PP samples. For this purpose each plasma treated PP solid sample (PP-Cu, PP-CuO, PP-Ag, PP-AgO) were shaken in $\mathrm{dH}_{2} \mathrm{O}$. The samples of solid PP were put into tubes with $45 \mathrm{~cm}^{3} \mathrm{dH}_{2} \mathrm{O}$ and agitated on the laboratory orbital shaker at $3,33 \mathrm{~Hz}$ for $1 \mathrm{~h}$. After this time, the PP samples were transferred to new tubes containing $45 \mathrm{~cm}^{3} \mathrm{dH}_{2} \mathrm{O}$ and agitated again for $1 \mathrm{~h}$. The process was conducted for $18 \mathrm{~h}$. Three subsamples were tested simultaneously for each type of PP. The concentrations of $\mathrm{Cu}$ ions were determined for $\mathrm{Cu}$ - and $\mathrm{CuO}$-coated PP samples while the levels of $\mathrm{Ag}$ were measured for the samples containing Ag- and AgO-coated PP samples after each hour of agitation in $\mathrm{dH}_{2} \mathrm{O}$. Prior to mineralization for
$\mathrm{T}$ a b l e 2. Operating parameters of ICP-MS

\begin{tabular}{c|c}
\hline Parameters & Values \\
\hline Forward power, $\mathrm{W}$ & 1548.6 \\
Cool gas flow, $\mathrm{dm}^{3} / \mathrm{min}$ & 13.956 \\
Auxiliary gas flow, $\mathrm{dm}^{3} / \mathrm{min}$ & 0.8021 \\
Nebulizer gas flow, $\mathrm{dm}^{3} / \mathrm{min}$ & 1.02464 \\
Dwell time, s & 0.005 \\
Number of replicates & 3 \\
\hline
\end{tabular}

$40 \mathrm{~min}$ at $160^{\circ} \mathrm{C}$ in DigiPrep Mini device (SCP Science), all of the samples containing solutions were acidified with $65 \% \mathrm{HNO}_{3}(\mathrm{POCH})$. After mineralization the concentrations were analysed with Inductively Coupled Plasma Mass Spectrometer (ICP-MS), iCAP Q, ThermoFisher Scientific. The detailed operating parameters for ICP-MS measurements were summarized in Table 2. The total Ag and $\mathrm{Cu}$ concentrations in solutions after leaching process were calculated for the polymer blank correction $(n=12)$, mean $0.34 \mu \mathrm{g} / \mathrm{dm}^{3}$ for $\mathrm{Cu}$ and $1.0 \mu \mathrm{g} / \mathrm{dm}^{3}$ for $\mathrm{Ag}$.

\section{Morphology and the composition of the coatings on PP}

The microstructure of the plasma treated polypropylene surface was characterized via images recorded with scanning electron microscope (SEM) Hitachi electron back-scatter detector with field emission and thermal emmitter SU-70 Schottky. The analyses were carried out in vacuum conditions $\left(1 \cdot 10^{-8} \mathrm{~Pa}\right)$ at an accelerating voltage of $15 \mathrm{kV}$ and a secondary electron reception angle of $30.4^{\circ}$, using the secondary electron detector (SE). The composition of elements occurred within deposited layers on solid PP were identified with EDS microanalysis. The tests were carried out in three sites of each polymer.

\section{Tests of antibacterial properties}

\section{Culture and growth conditions}

The antimicrobial properties of the plasma-coated PP samples were examined against two model bacterial species from the groups of Gram-negative (G-) - Escherichia coli (ATCC 25922) Gram-positive (G+) - Staphylococcus aureus (ATCC 25923) and derived from American Type Culture Collection. Prior to microbiological tests, the samples of solid polymers were disinfected with $96 \%$ ethanol and additionally sterilized under UV-C light for $30 \mathrm{~min}$. Cultures of bacteria were prepared by inoculating $20 \mathrm{~cm}^{3}$ of LB containing flasks with $0.01 \mathrm{~cm}^{3}$ of a liquid culture at stationary phase of growth. The cultures were agitated at $37^{\circ} \mathrm{C}$ in the incubator overnight.

\section{Static contact}

Overnight cultures of E.coli and S. aureus in the volume of $0.1 \mathrm{~cm}^{3}$ were transferred with a pipette and loop-spread onto the surfaces of the plasma treated polypropylene. As 
a reference sample the untreated PP was used. All samples were placed on sterile Petri dishes in a wet chamber containing $5 \mathrm{~cm}^{3}$ of phosphate buffered saline (PBS) to maintain appropriate humidity. The samples of PP were cultured overnight without agitation and then transferred to the separate sterile flasks containing $9.9 \mathrm{~cm}^{3}$ of PBS ( $\mathrm{pH}$ 7.0). In such conditions they were agitated in the orbital shaker for $5 \mathrm{~min}$ to remove attached bacteria. The serial dilutions from the agitated buffer solutions were plated on LB Miller agar. After $18 \mathrm{~h}$ of incubation at $37^{\circ} \mathrm{C}$ the number of viable bacteria (colonies) was counted and the results were expressed as reduction in cell viability $(\%)$. Each test was performed three times $(n=3)$.

\section{Dynamic contact}

The antibacterial tests under dynamic conditions were conducted according to the procedure of ASTM E2149 (Standard Test Method for Determining the Antimicrobial Agents Under Dynamic Contact Conditions) involving slight changes of the method [29]. For the tests the pottasium diphosphate $\left(\mathrm{KH}_{2} \mathrm{PO}_{4}\right)$ buffer was prepared in the ratio 1 : $800(v)$ from $0.25 \mathrm{M} \mathrm{KH}_{2} \mathrm{PO}_{4}$ stock solution $(\mathrm{pH} 7.0)$ and sterilized. In order to establish the concentration (1.53.0) $\cdot 10^{8} \mathrm{CFU} / \mathrm{cm}^{3}$ (CFU - colony forming unit) of bacterial working solutions in $\mathrm{KH}_{2} \mathrm{PO}_{4}$ the overnight cultures of E.coli and S.aureus were suspended in the separate buffer containing tube and the absorbance was measured $0.28 \pm 0.02$ at the wavelength of $475 \mathrm{~nm}$ using spectrophotometer Hach DR 6000. The suspensions of bacteria were appropriately dilluted in saline buffer to obtain the final concentration of $(1.5-3.0) \cdot 10^{5} \mathrm{CFU} / \mathrm{cm}^{3}$. The volume of $25 \mathrm{~cm}^{3}$ of bacterial suspensions were transferred to the flasks with plasma-treated and untreated samples of PP before and after $18 \mathrm{~h}$ process of leaching in $\mathrm{dH}_{2} \mathrm{O}$. Then, they were shaken at $3.33 \mathrm{~Hz}$ at room temperature for $3 \mathrm{~h}$. The samples of bacterial suspensions after each $1 \mathrm{~h}$ of dynamic contact were transferred onto LB Miller agar plates and left overnight for incubation at $37^{\circ} \mathrm{C}$ for $\mathrm{CFU}$ counts. Each test was performed three times $(n=3)$.

\section{RESULTS AND DISCUSSION}

\section{The influence of plasma treatment on contact angle changes}

Plasma treatment of PP samples with $\mathrm{Cu}, \mathrm{CuO}, \mathrm{Ag}$ and $\mathrm{AgO}$ enables smooth and uniform covering of their surface. The measurements of contact angle were taken from 8 points of the untreated and treated PP samples and the standard deviation was calculated. The contact angle determined the level of wettability of a solid by a liquid [30]. All of the tested coatings increased the contact angle values for $\mathrm{dH}_{2} \mathrm{O}$ compared to the native PP (Fig. 1).

The highest contact angle values were observed for AgO-coated PP sample which was over $20^{\circ}$ higher than untreated PP samples. This indicates that the wettability

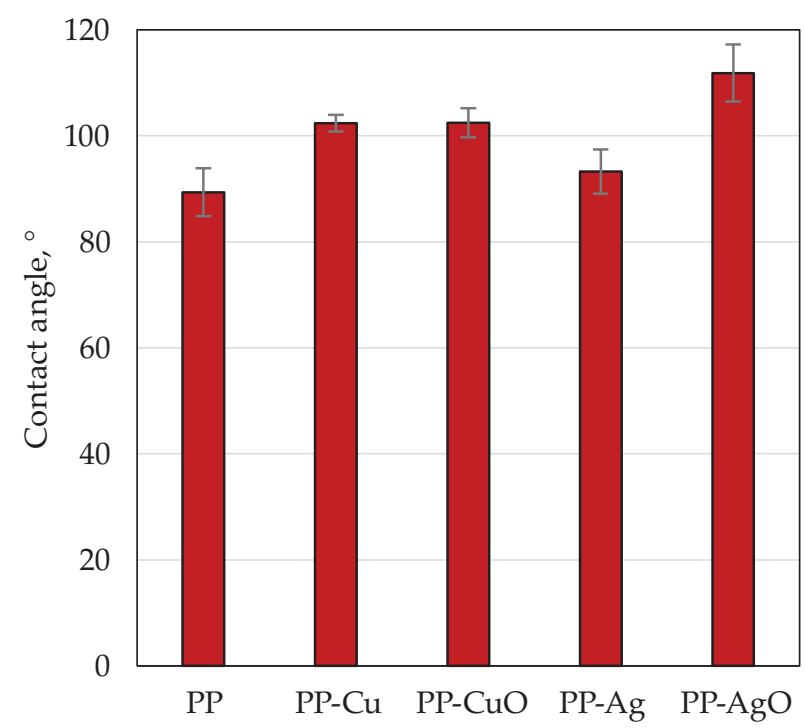

Fig. 1. Contact angle values of the solid PP samples $(n=8)$ : untreated (PP) and plasma-treated with $\mathrm{Cu}, \mathrm{CuO}, \mathrm{Ag}$ and $\mathrm{AgO}$

of the surface of AgO-coated PP significantly decreased, which was not visible for metallic Ag coating. Plasma deposition of $\mathrm{Cu}$ and $\mathrm{CuO}$ also resulted in slight and similar increase of contact angle values for $\mathrm{dH}_{2} \mathrm{O}$. The obtained results suggest that $\mathrm{PP}$ materials coated with $\mathrm{AgO}, \mathrm{Cu}$ as well as $\mathrm{CuO}$ may reveal self-cleaning properties, which can be particularly important for the polypropylene elements exposed to pollutions including biological ones [31]. Depending on the specific final application, this change may be either positive or negative. It was found that hydrophobic character of the coating may affect biofilm formation. According to Faille et al. [32] there is a direct link between hydrophobicity and adherence of $E$. coli to a range of different substrates. Although this was a promising result, it was not in agreement with the study that has shown that hydrophilicity may have little effect on biofilm formation [33]. Antifouling coatings do not kill the microbes directly but instead prevent the attachment of bacteria on the surfaces that allow the formation of biofilms. Newly emerged trend to design antibacterial strategy involve creating superhydrophobic surfaces that give promising capability of reducing bacterial adhesion together with an easy removal of bacteria cells. Therefore, the selection of appropriate bactericidal compounds to be deposited via PVD techniques on the surface of polymer material may greatly contribute to both reduction of microbial attachment and release of biocides.

\section{Leaching of metals from PP-coatings}

The effects of $\mathrm{Cu}$ and $\mathrm{Ag}$ leaching from the surface of plasma-treated PP samples were examined after contact of the samples with $\mathrm{dH}_{2} \mathrm{O}$ under dynamic conditions (Fig. 2, Fig. 3).

In Fig. 2. it was illustrated how the stability of $\mathrm{Cu}$ plasma deposited PP was affected by agitation of the samples for $18 \mathrm{~h}$ in $\mathrm{dH}_{2} \mathrm{O}$. It was noticed that the concentration 


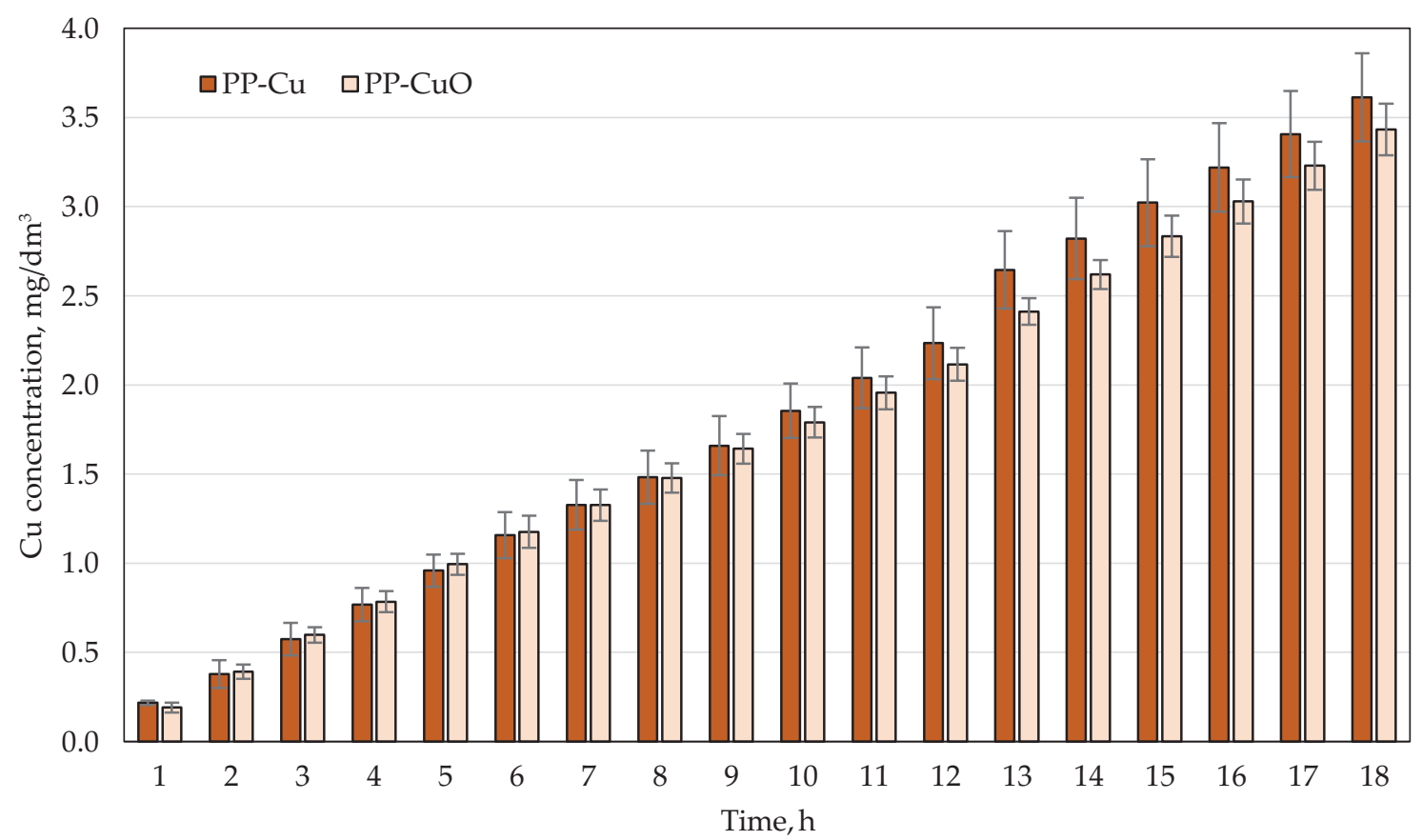

Fig. 2. The concentrations of $\mathrm{Cu}$ after specific time of $\mathrm{Cu}$ - and $\mathrm{CuO}$-plasma treated PP samples contact with $\mathrm{dH}_{2} \mathrm{O}$

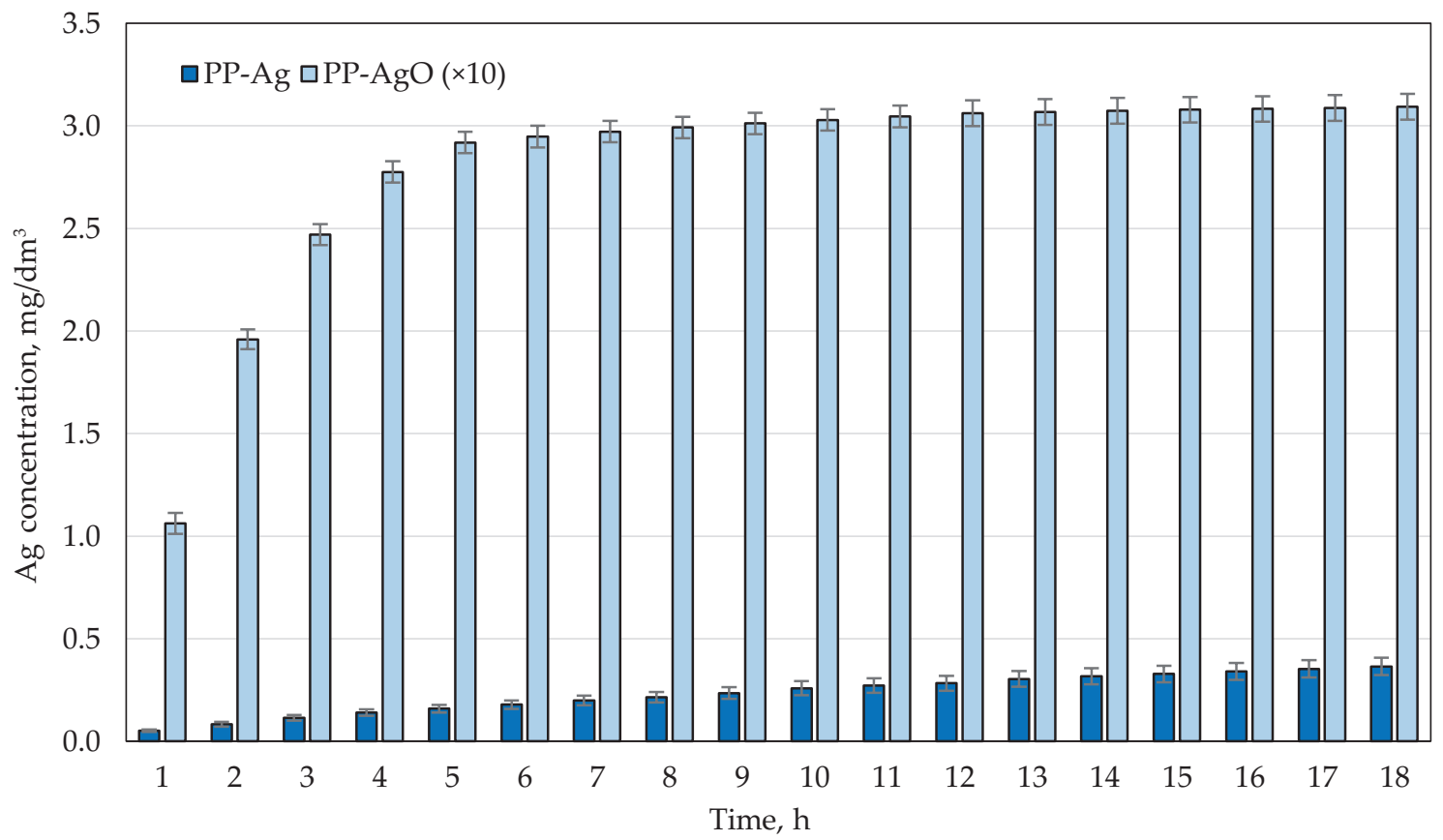

Fig. 3. The concentrations of Ag after specific time of Ag- and AgO-plasma treated PP samples contact with $\mathrm{dH}_{2} \mathrm{O}$

of $\mathrm{Cu}$ leached from both $\mathrm{Cu}$ and $\mathrm{CuO}$ coatings was similar after each hour of the contact of PP with $\mathrm{dH}_{2} \mathrm{O}$. The total concentration of $\mathrm{Cu}$ after $18 \mathrm{~h}$ of agitation was similar $3.61 \mathrm{mg} / \mathrm{dm}^{3} \pm 0.25 \mathrm{mg} / \mathrm{dm}^{3}$ and $3.43 \mathrm{mg} / \mathrm{dm}^{3} \pm 0.15 \mathrm{mg} / \mathrm{dm}^{3}$ for both $\mathrm{Cu}$ and $\mathrm{CuO}$ coatings, respectively. Also the average increase in $\mathrm{Cu}$ amount for both coatings after subsequent hours of leaching was similar and equal to $0.20 \mathrm{mg} / \mathrm{dm}^{3}$ and $0.19 \mathrm{mg} / \mathrm{dm}^{3}$, respectively.

In Fig. 3 the change in the concentration of $\mathrm{Ag}$ leached out from $\mathrm{PP}$ samples treated with $\mathrm{Ag}$ and $\mathrm{AgO}$ in $\mathrm{dH}_{2} \mathrm{O}$ was represented. Large differences in the leaching of $\mathrm{Ag}$ from both coatings were observed. The total concentration of Ag after $18 \mathrm{~h}$ of agitation was $0.365 \mathrm{mg} / \mathrm{dm}^{3} \pm 0.042 \mathrm{mg} / \mathrm{dm}^{3}$ and $30.93 \mathrm{mg} / \mathrm{dm}^{3} \pm 0.63 \mathrm{mg} / \mathrm{dm}^{3}$ for $\mathrm{Ag}$ and $\mathrm{AgO}$ coating, respectively. The obtained results showed that the Ag concentration was increasing over time in both cases, yet the initial concentration in $\mathrm{dH}_{2} \mathrm{O}$ after $1 \mathrm{~h}$ contact with PP treated with Ag was about 85 times lower than the sample of PP treated with AgO. It was observed that the coating based on $\mathrm{AgO}$ showed low stability particularly in the first hours of the process, while the concentration of $\mathrm{Ag}$ in solutions after leaching was 
high $-29.2 \mathrm{mg} / \mathrm{dm}^{3} \pm 3.6 \mathrm{mg} / \mathrm{dm}^{3}$ for $5 \mathrm{~h}$, which constitutes $94 \%$ of the total concentration of $\mathrm{Ag}$ leached out after $18 \mathrm{~h}$ of the process. In the last $6 \mathrm{~h}$ of the leaching process, increase in Ag level was smaller and stabilized at $50 \mu \mathrm{g} /\left(\mathrm{dm}^{3} \cdot \mathrm{h}\right)$. However, for the coating based on $\mathrm{Ag}$, it was observed that the increase in concentration of $\mathrm{Ag}$ is linear, on average about $20 \mu \mathrm{g} / \mathrm{dm}^{3}$ for each hour of the leaching process.

High leaching of Ag from AgO-treated PP and its low stability in water likely relates to the state of stresses occuring in the coating [34]. The level of stresses and thus stability in the coatings is influenced by the rate of coating deposition and kinetic energy of ions in the chamber, which are dependent on the chosen method and the parameters of the deposition process [35]. Research groups so far have only been studying mechanical properties of the deposited coatings on various materials including polymers [36-39]. There is a lack of literature data on the stability and durability of plasma coatings on polymers in terms of using with aqueous conditions as well as both their antibacterial properties in conditions simulating surface attachment and biofilm formation (static
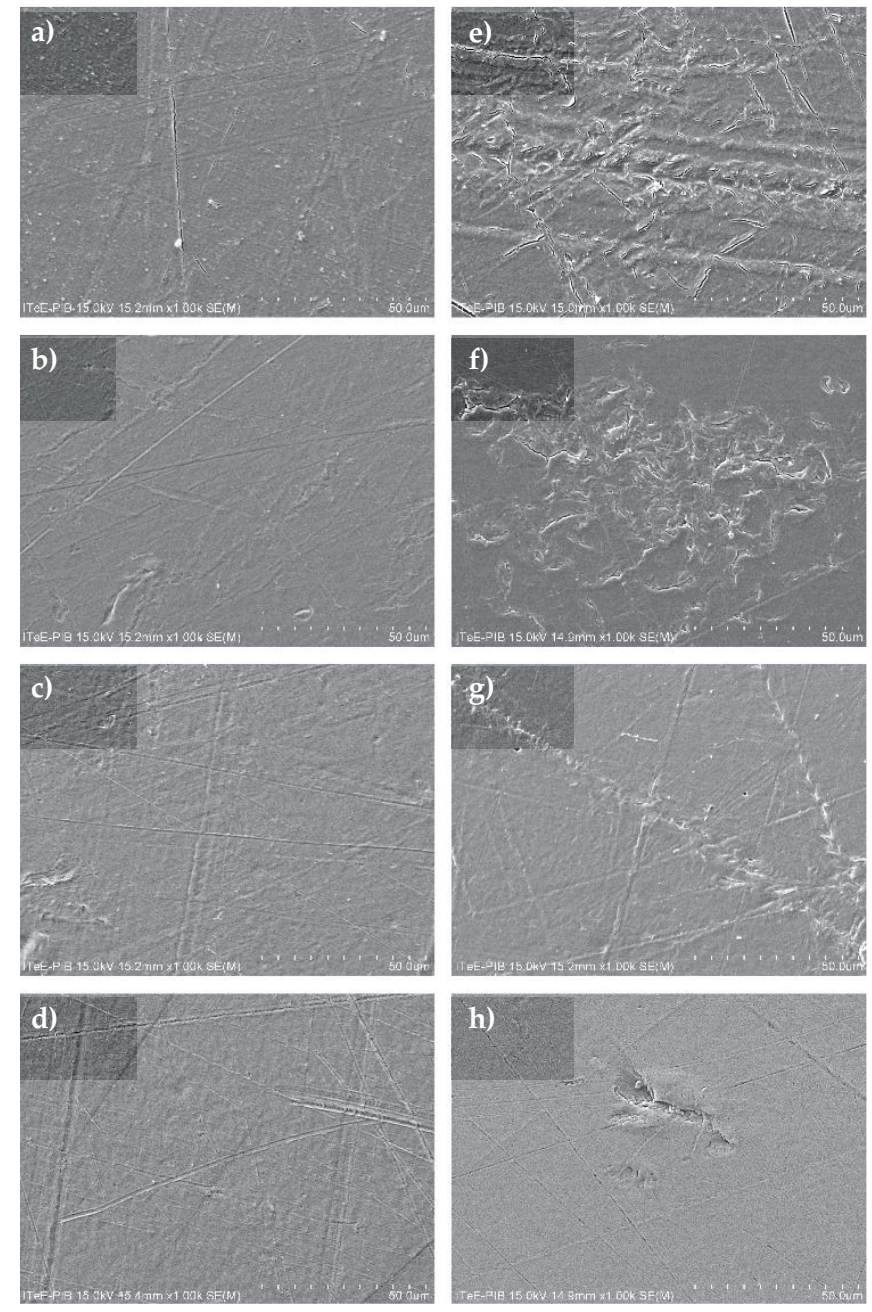

Fig. 4. SEM images of plasma coated polypropylene samples: a-d) before leaching process: $\mathrm{Cu}, \mathrm{CuO}, \mathrm{Ag}$, $\mathrm{AgO}$, respectively; e-h) after leaching process: $\mathrm{Cu}, \mathrm{CuO}, \mathrm{Ag}, \mathrm{AgO}$, respectively contact) and flow of biologically contaminated waters (dynamic contact). Presented results are novel approach to examine stability of metallic-based coatings on polypropylene materials.

\section{The influence of leaching on the morphology and microstructure of the PP-coating}

Analyses with SEM allowed to image the morphology of polypropylene after plasma deposited coatings containing $\mathrm{Cu}, \mathrm{CuO}, \mathrm{Ag}$ and $\mathrm{AgO}$ (Fig. 4).

The obtained results showed that deposited layers are smooth and only several cracks were observed. After leaching process the morphology of treated PP was slightly changed. For all of the samples more discontinuities in the deposited layers were observed. Particularly, the polymer treated with $\mathrm{Cu}$ and $\mathrm{CuO}$ revealed abruptions which may be associated with the observed constant release of the metal ions from the coating.

EDS analysis showed the alterations in the composition of elements on particular PP samples expressed as atomic concentration before leaching process and after contact with $\mathrm{dH}_{2} \mathrm{O}$ (Fig. 5). The presented results are average values obtained from three sites of each polymer.

The composition of samples coated with $\mathrm{Cu}$ were practically unchanged after contact with $\mathrm{dH}_{2} \mathrm{O}$, as the atomic concentrations of $\mathrm{Cu}$ were similar and equal to $98.1 \% \mathrm{Cu}$ before and $97.4 \% \mathrm{Cu}$ after leaching. In the case of coating based on $\mathrm{CuO}$, no significant changes were observed in the atomic concentration before and after leaching process, which was $92.5 \%$ and $91.2 \% \mathrm{Cu}$, respectively. Ag-coated PP results showed that atomic concentration of $\mathrm{Ag}$ on the surface of polymer was the same for both samples before and after leaching process (98.6\%). The interesting results were obtained for $\mathrm{AgO}$ treated polymer. The atomic concentration of particular elements

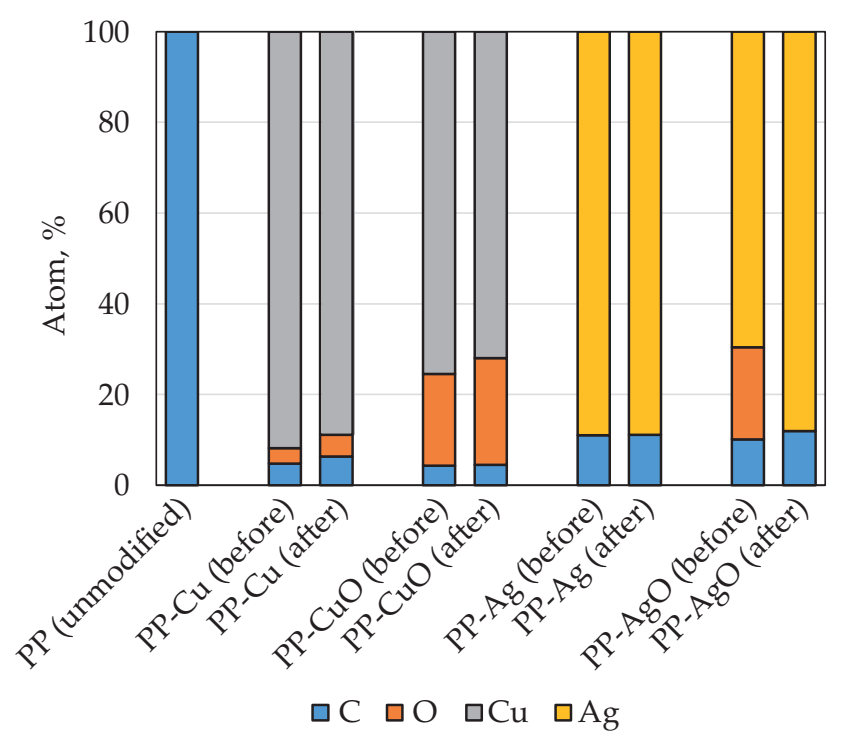

Fig. 5. Elements composition (at. \%) of plasma treated PP samples before and after leaching process 
in this coating before the leaching process was different compared to the atomic composition after the leaching process. It was observed that after leaching process, the oxygen was completely removed from the coating, while the atomic percentage of silver increased (from $94.4 \%$ Ag before to $98.5 \%$ after the leaching process). This may indicate that the parameters of the AgO plasma deposition process resulted in a non-uniform structure of the coating and thus a varying degree of leached ions over time. This finding was confirmed by the results obtained for AgO treated sample during the analysis of Ag concentration in the solutions after the process of leaching (Fig. 3), while the concentration of Ag in the first hours of the process was very high. The stabilization of silver from the $\mathrm{AgO}$ coating during the final hours of the process may indicate that the obtained coating was loosely attached within the surface layer, yet its cohesion increased with

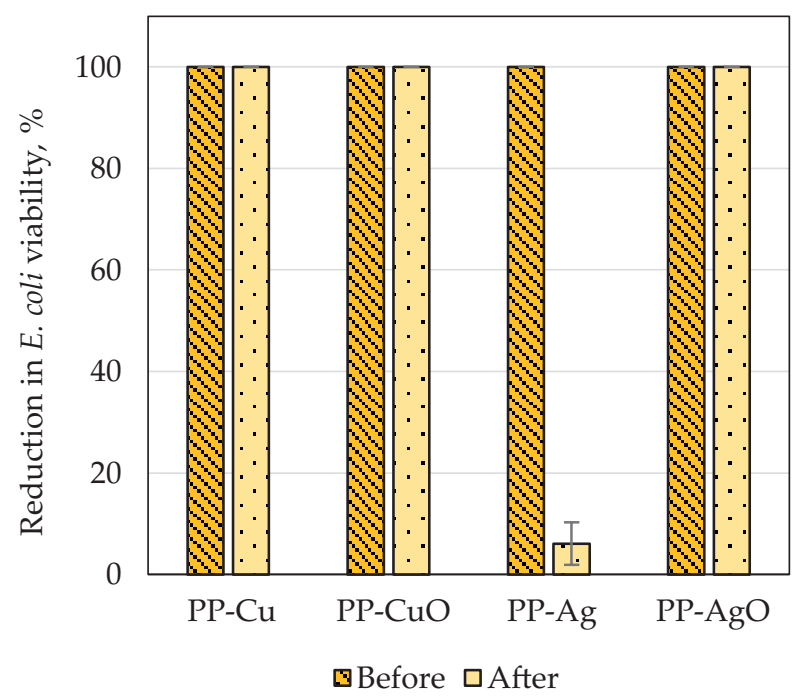

Fig. 6. Reduction in $E$. coli viability after $18 \mathrm{~h}$ static contact with the plasma treated PP samples before and after leaching $(n=3)$ the depth of the coating. Similar results of atomic concentrations of elements obtained for $\mathrm{Ag}$ and $\mathrm{AgO}$ coatings after the leaching process $(98.6 \%$ and $98.5 \%$, respectively) may indicate that the produced $\mathrm{AgO}$ coating might have a "layered" structure - the internal layer of the coating deposited on the PP polymer was a solid layer of Ag, and the external layer was composed of AgO characterized by loose bindings leading to higher leaching effect.

\section{Antibacterial properties of PVD-coated samples}

The antimicrobial performance of plasma treated polypropylene samples was assessed against two representative bacteria E. coli and S. aureus in static (non-stirred) conditions simulating biofouling formation on the surface of the samples and to avoid potentially forced releasement of metal ions. A dynamic test was performed for the same microbial species to assess the bactericidal effectiveness of treated PP samples imitating their application in aqueous conditions. Both tests were performed for the originally plasma treated samples (before leaching process) and for the samples after $18 \mathrm{~h}$ contact (agitation) with $\mathrm{dH}_{2} \mathrm{O}$.

Figure 6 represents the percentage reduction in cell viability of $E$. coli in static conditions before and after leaching process. It was found that $\mathrm{Cu}$ and $\mathrm{CuO}$ as well as Ag and AgO treated PP samples tested before leaching process completely eliminated E. coli. However, after leaching process only Ag-treated PP was significantly less effective, as it only resulted in $6 \%$ reduction of cell viability, which was probably associated with the releasing of less amount of Ag ions to the surrounding environment due to non-stirred conditions.

Figure 7 shows the performance of plasma treated samples against $E$. coli under dynamic conditions revealing that all of the samples are as same highly efficient in kil-

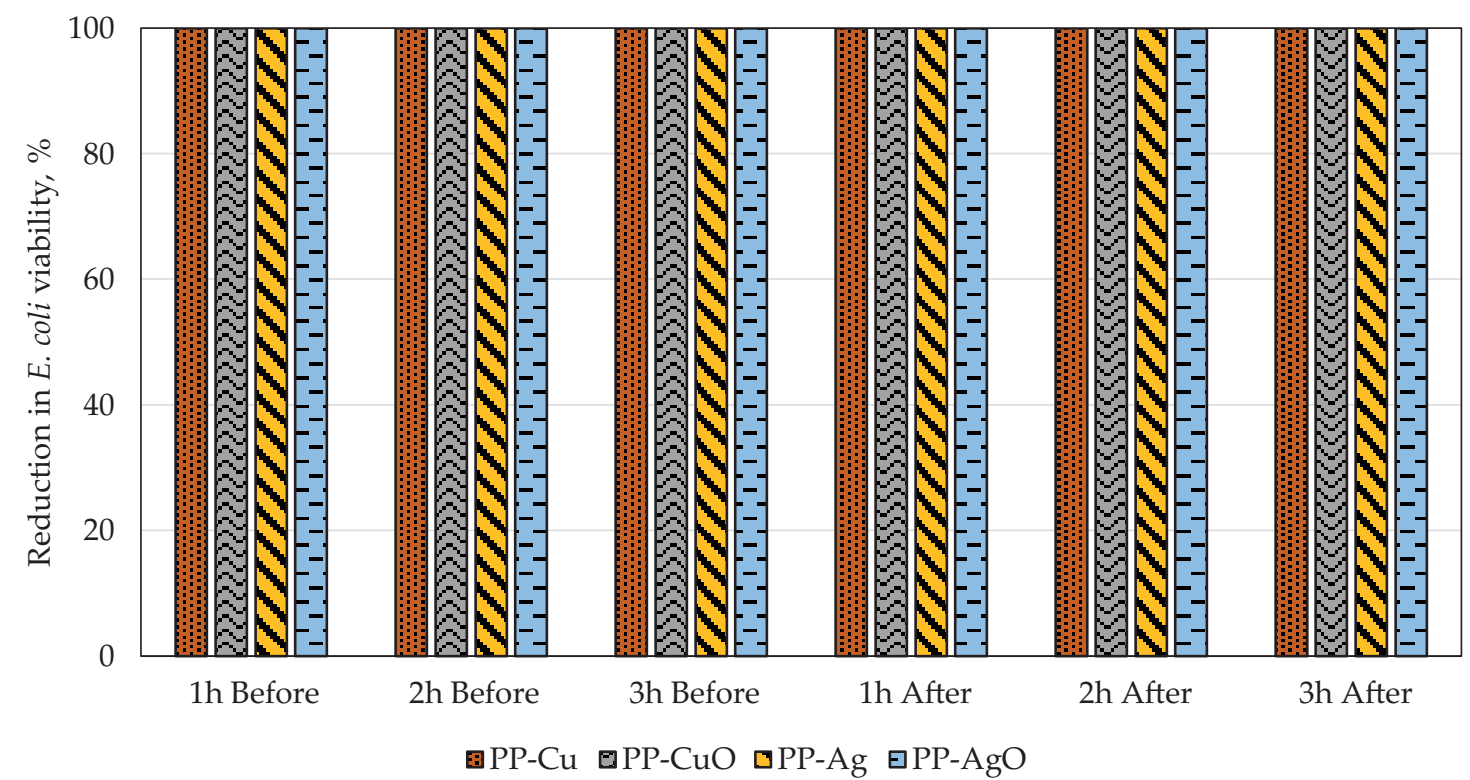

Fig. 7. Reduction in E. coli cell viability after 1, 2 and $3 \mathrm{~h}$ of dynamic contact with plasma treated PP samples before and after leaching $(n=3)$ 
ling all of the bacteria regardless the samples were before or after leaching process (after contact with $\mathrm{dH}_{2} \mathrm{O}$ ).

Similar results were obtained for $S$. aureus (Fig. 8 and Fig. 9). It was noted that in static conditions all of the plasma treated samples before leaching process resulted in almost total reduction of $S$. aureus cell viability. Copper and copper oxide coated PP-samples after $18 \mathrm{~h}$ leaching process (agitation in $\mathrm{dH}_{2} \mathrm{O}$ ) were as same efficient against S. aureus as before. However, Ag and AgO coated PP samples after prior contact with $\mathrm{dH}_{2} \mathrm{O}$ resulted in less visible bactericidal effect.

Under dynamic conditions conducted for $3 \mathrm{~h}$, only Ag-treated sample did not result in strong bactericidal activity in $1 \mathrm{~h}$ of dynamic contact, which was similar for both types of samples: before and after leaching process (Fig. 9). It was also found that antibacterial effect of Ag-PP

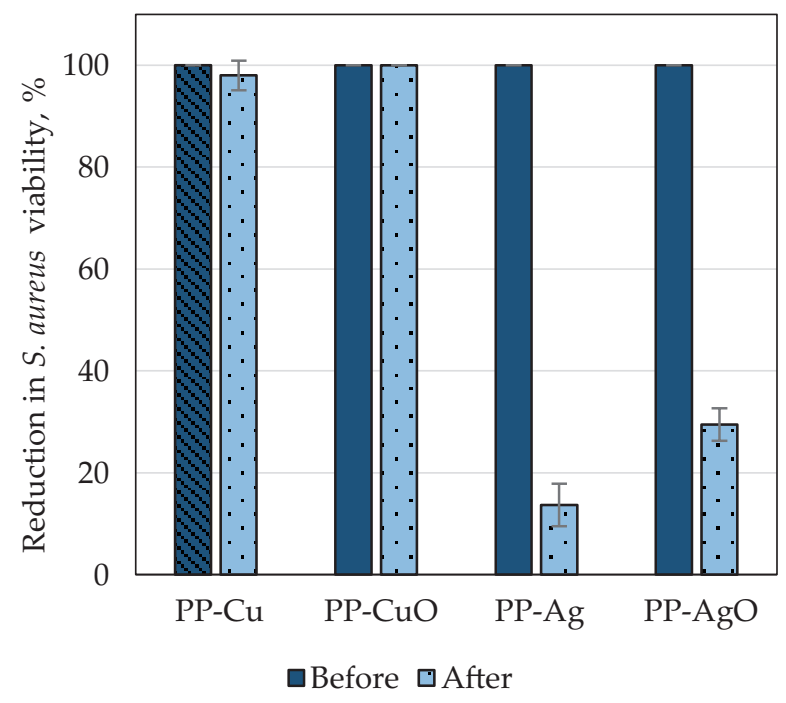

Fig. 8. Reduction in S. aureus viability after $18 \mathrm{~h}$ static contact with the plasma treated PP samples before and after leaching $(n=3)$ was increasing over time which was associated with the increasing concentration of $\mathrm{Ag}$ ions in the solution. This phenomena can be explained by results obtained for leaching test of Ag-PP samples, while it was confirmed that the Ag-coating is undoubtedly the most stable one, as the metal ions release in small amounts and slowest from the polypropylene surface.

These results suggest that antibacterial properties of treated samples are strongly related to the release of ions from the coatings in bacterial environment and it was more visible when the samples were agitated under dynamic conditions forcing leaching of the ions. Despite the fact that the Ag-treated PP was the most stable one, the levels of ions leaching out from the polymer samples was sufficient to kill bacteria. There are various theories on the action of silver on microbes to cause the microbicidal effect. One of them is that ions can interact with the thiol groups of many vital enzymes of bacteria and inactivate them. The bacterial cells in contact with silver take in silver ions, which inhibit several functions in the cells. It was also proposed that generation of reactive oxygen species, which are produced possibly through the inhibition of a respiratory enzyme by silver ions may attack the cell themselves [40]. This clearly confirms that releasing of ions and their concentration plays a major role in eliciting bactericidal properties of surface-modified materials. However, S. aureus $\left(\mathrm{G}^{+}\right)$was less prone to the $\mathrm{Ag}$ ions compared to E. coli (G-) as it was reported that it created a defense system against the inhibitory effects of $\mathrm{Ag}$ ions [41, 42]. Antibacterial assay conducted in the study revealed that copper ions released from $\mathrm{Cu}$ and $\mathrm{CuO}$ coatings turned out to be highly efficient against both $\mathrm{G}+$ and G- bacteria independently the tested samples were before or after leaching process. This might be associated with the constant release of the same bactericidal concentration of ions in time as it was shown in previous section. In the

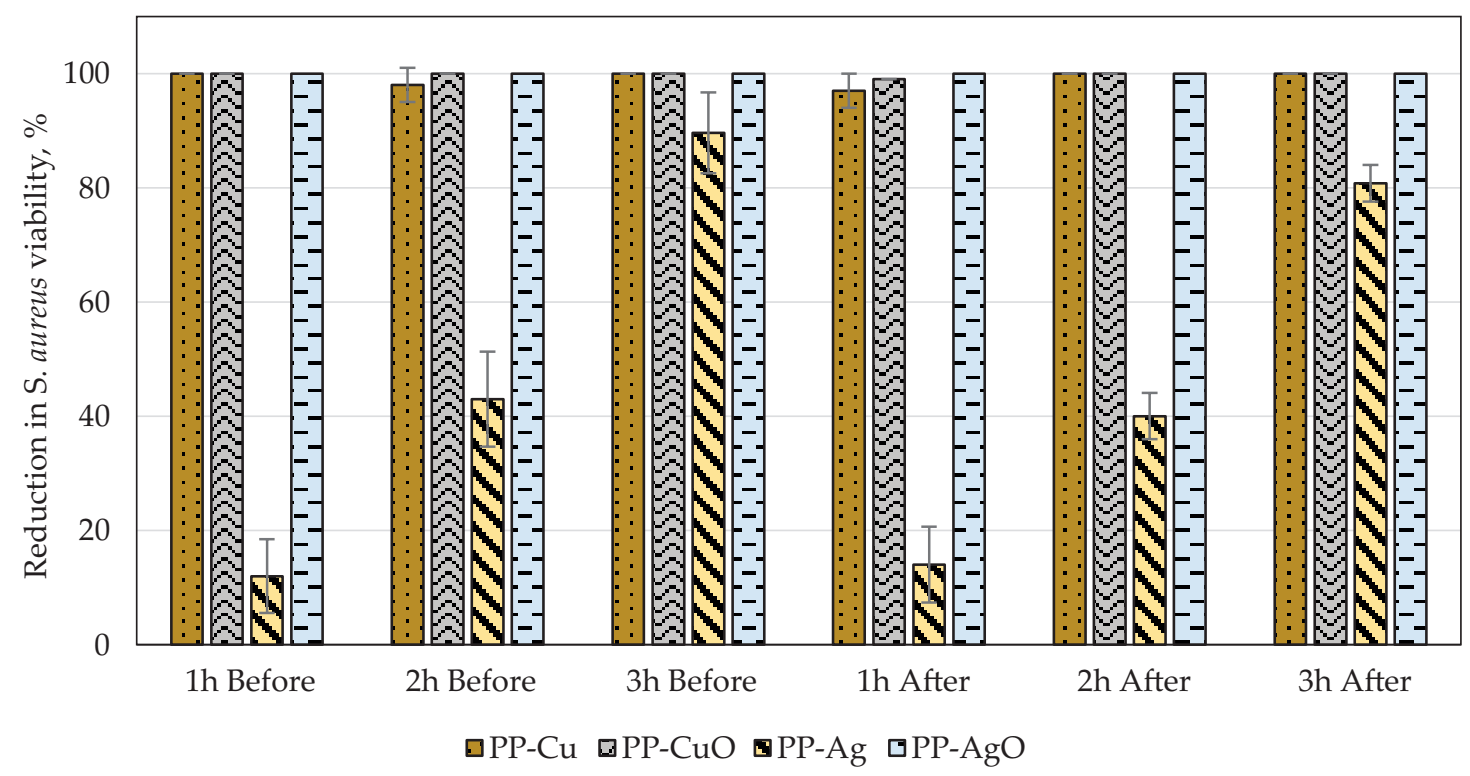

Fig. 9. Reduction in S. aureus cell viability after 1, 2 and $3 \mathrm{~h}$ of dynamic contact with plasma treated PP samples: a) before, b) after leaching $(n=3)$ 
case of copper-based surfaces it was found that particularly $\mathrm{Cu}^{2+}$ play a key role in creating defects in microbial cells by changing conformational structure of nucleic acids and proteins, besides reactive oxidative stress generation [43]. Various laboratory and clinical studies have confirmed that solid copper surfaces promote rapid killing of both G- and G+ bacteria. In antibacterial activity performance of antibacterial compounds the crucial issue involves the differences in the thickness of bacterial cell wall between species. It has been already concluded that biofilms of G- species with a thinner cell wall are inactivated more rapidly with several microbicidal agents than biofilms of $\mathrm{G}+$ bacteria with a thicker cell wall $[42,44]$. Generally, the mechanism underlying antibacterial behavior of metals includes the attachment of metal particles to the surface of cell membrane, catalyzed radical formation and release of metal ions [15]. Metal-based coatings deposited on the surface of polymers provide a versatile path to take advantages of their antibacterial properties manufacturing new generation biocide materials and allowing the extension of potential applications. Surface treatment of polymer involving slow and constant release of metal ions greatly contributes to antimicrobial behavior.

\section{CONCLUSIONS}

In the study a novel approach combining interdisciplinary science such as materials, physics, chemistry and biotechnology was presented to give an insight into new trends toward development of polymer-based materials. Surface engineering technologies including MS-PVD technique enables imparting novel functional properties to a range of polymeric materials. In the present work, polypropylene samples were coated using MS-PVD with silver- and copper-based layers so as to provide antimicrobial properties to the polymeric material. The samples of polypropylene functionalized with plasma deposited silver and copper compounds were examined in terms of wettability, morphology, composition and stability of the coatings in aqueous solution. It was found that the hydrophobicity for all of the samples treated with metals and their oxides increased as compared to unmodified PP sample, except Ag-PP which resulted in contact angle similar to that of original PP. The obtained Cu-PP and $\mathrm{CuO}-\mathrm{PP}$ coatings did not vary to each other significantly in terms of wettability, morphology, composition and stability. The exposure of $\mathrm{Cu}$ and $\mathrm{CuO}$ plasma treated samples to $\mathrm{dH}_{2} \mathrm{O}$ showed that ions of metals were linearly released in time, and their concentrations in aqueous solution were sufficient to completely eliminate both G+ and G- bacteria using static and dynamic contact method. However, the properties of Ag-PP and AgO-PP were significantly different. The leaching of silver ions from Ag-PP during contact with $\mathrm{dH}_{2} \mathrm{O}$ was relatively low and was about $20 \mu \mathrm{g} /\left(\mathrm{dm}^{3} \cdot \mathrm{h}\right)$. Nevertheless, the dynamic contact of inoculum with Ag-treated PP showed that the concentration of leached ions was sufficient to com- pletely remove $E$. coli before contact of $\mathrm{Ag}$-PP with $\mathrm{dH}_{2} \mathrm{O}$, but insufficient to kill $S$. aureus for both before and after contact of Ag-PP sample with $\mathrm{dH}_{2} \mathrm{O}$ (leaching). It was demonstrated that antimicrobial activity of the material was maintained at similar level after the leaching process. Antibacterial activity against $S$. aureus was higher as the contact time of the Ag-PP sample with bacterial inoculum was longer, which was due to the linear dependence of silver ions release (constant increase in ions concentration over time). Although the Ag-PP samples were characterized by high antibacterial performance against two bacterial strains before leaching, this activity significantly decreased after leaching process in static contact. It resulted from avoiding mechanically forced leaching of ions (static contact method) from the polymer surface. The sample of AgO-PP due to its low stability under water conditions resulted in complete removal of both $E$. coli and $S$. aureus bacterial cells in static and dynamic conditions. The ion leaching in $\mathrm{dH}_{2} \mathrm{O}$ over time was changing and in the final hours of the leaching process reaching about $50 \mu \mathrm{g} /\left(\mathrm{dm}^{3} \cdot \mathrm{h}\right)$ and it was sufficient to completely remove E. coli in both static and dynamic contact, but too low to remove $S$. aureus in static conditions. The morphology and composition of AgO-PP sample after the leaching process and the study on its bactericidal properties revealed that selected parameters of MS-PVD treatment were not appropriate to obtain AgO over the entire depth of the coating. It is likely due to the mixture of $\mathrm{Ag}$ and AgO occurring within the coating, which was confirmed by the similar atomic concentrations of the elements on the surface of PP obtained for both Ag (before and after the leaching process) and AgO coating (after the leaching process). This was also confirmed by bactericidal tests using static contact method resulting in lower concentration of silver ions available for bacteria to elicit appropriate toxicity compared to dynamic contact method.

The reason of the differences in the results on antimicrobial activity between the same samples are due to the methodological variations within static and dynamic conditions, which used together complement understanding the mechanism underlying antimicrobial activity of material produced via surface treatment with plasma. It was found that the key aspects of bactericidal properties of plasma treated polypropylene are the leaching of metal ions from the surface of the material, their amount released into the environment of bacterial cells, operating conditions of plasma deposition as well as the type of bacterial strain. Due to some differences in their cell structures and developed defense mechanisms, they may have different sensitivity to certain metal ions.

To sum up, plasma treatment of polymers showed bactericidal properties and may be potentially used in many sectors. Further research is necessary to support the development of innovative biocide-based materials to be used in medicine, pharmacy and food industry, preventing attachment of variety of microorganisms, biofilm formation and potentially associated diseases. Future area of inves- 
tigations should include scaling up the process for a particular application, optimization, control of ion leaching along with safety and potential toxicity to human health.

This work was financially supported by National Science Center in the Project No. 2016/23/N/ST5/01088.

\section{REFERENCES}

[1] Maitz M.F.: Biosurface and Biotribology 2015, 1, 161. https://doi.org/10.1016/j.bsbt.2015.08.002

[2] Sorrentino A., Gorrasi G., Vittoria V.: Trends in Food Science \& Technology 2007, 18, 84. https://doi.org/10.1016/j.tifs.2006.09.004

[3] North E.J., Halden R.U.: Reviews on Environmental Health 2013, 28, 1.

https://doi.org/10.1515/reveh-2012-0030

[4] Jamal M., Ahmad W., Andleeb S. et al.: Journal of the Chinese Medical Association 2018, 1, 7. https://doi.org/10.1016/j.jcma.2017.07.012

[5] Kołwzan B.: Ochrona Srodowiska 2011, 33, 3.

[6] Tilahun A., Haddis S., Teshale A. et al.: International Journal of Microbiological Research 2016, 3, 63. https://doi.org/10.5829/idosi.ijmr.2016.63.73

[7] Vanysacker L., Denis C., Declerck P. et al.: BioMed Research International 2013, 1.

http://dx.doi.org/10.1155/2013/470867

[8] Sztuk-Sikorska E., Gradoń L.: Chemical and Process Engineering 2016, 37, 319.

https://doi.org/10.1515/cpe-2016-0026

[9] Kowalik-Klimczak A., Stanisławek E.: Desalination and Water Treatment 2018, 128, 364. https://doi.org/10.5004/dwt.2018.22981

[10] Ham S.Y., Kim H.-S., Jang Y. et al.: Fuel 2019, 250, 79. https://doi.org/10.1016/j.fuel.2019.03.145

[11] Kowalik-Klimczak A., Stanisławek E., Kacprzyńska-Gołacka J. et al.: Desalination and Water Treatment 2018, 128, 243.

https://doi.org/10.5004/dwt.2018.22868

[12] Gizaw M., Thompson J., Faglie A. et al.: Bioengineering 2018, 5, 9. https://doi.org/10.3390/bioengineering5010009

[13] Smithers G.W., International Dairy Journal 2015, 48, 2. https://doi.org/10.1016/j.idairyj.2015.01.011

[14] Brunetti A., Macedonio F., Barbieri G. et al.: Environmental Engineering Research 2015, 20, 307. https://doi.org/10.4491/eer.2015.074

[15] Palza H.: International Journal of Molecular Sciences 2015, 16, 1099. https://doi.org/10.3390/ijms16012099

[16] Rzanek-Boroch Z., Dziadczyk P., Czajkowska D. et al.: EPJ Applied Physics 2013, 61, 24316. https://doi.org/10.1051/epjap/2012120410

[17] Gancarz I., Poźniak G., Bryjak M. et al.: Acta Polymerica 1999, 50, 317.

h t t p: // d oi or g / 10.1002 / ( S I C I) 1521 4044(19990901)50:9<317::AID-APOL317>3.0.CO;2-Q
[18] Ho C.H., Tobis J., Sprich C. et al.: Advanced Materials 2004, 16, 957. https://doi.org/10.1002/adma.200306253

[19] Delgado K., Quijada R., Palma R. et al.: Letters in Applied Microbiology 2011, 1, 50. https://doi.org/10.1111/j.1472-765X.2011.03069.x

[20] Ren G., Hub D., Cheng E.W.C.: International Journal of Antimicrobial Agents 2009, 33, 587.

https://doi.org/10.1016/j.ijantimicag.2008.12.004

[21] Park H.J., Kim J.Y., Kim J. et al.: Water Resource 2009, 431027.

https://doi.org/10.1016/j.watres.2008.12.002

[22] Thomas S., Mozetič M., Cvelbar U.: “Non-Thermal Plasma Technology for Polymeric Materials Applications in Composites, Nanostructured Materials and Biomedical Fields", Elsevier Science, United States 2018.

[23] Cruz M.C., Ruano G., Wolf M. et al.: Chemical Engineering Research and Design 2015, 94, 524. https://doi.org/10.1016/j.cherd.2014.09.014

[24] Ciszewski A., Gancarz I., Kunicki J. et al.: Surface \& Coatings Technology 2006, 201. https://doi.org/3676, 10.1016/j.surfcoat.2006.08.146

[25] Kacprzyńska-Gołacka J., Kowalik-Klimczak A., Skowroński J. et al.: Polimery 2018, 63, 353. https://doi.org/10.14314/polimery.2018.5.4

[26] Mazurkiewicz A., Smolik J.: Archives of Metallurgy and Materials 2015, 60, 2161. https://doi.org/10.1515/amm-2015-0362

[27] Mazurkiewicz A.: „Nanonauki i nanotechnologie. Stan i perspektywy rozwoju". Wydawnictwo Instytutu Technologii Eksploatacji - Państwowego Instytutu Badawczego, Radom 2007.

[28] Marambio-Jones C., Hoek E.M.V.: Journal of Nanoparticle Research 2010, 12, 1531. https://doi.org/10.1007/s11051-010-9900-y

[29] ASTM E2149-13a Standard Test Method for Determining the Antimicrobial Agents Under Dynamic Contact Conditions, 2013. https://doi.org/10.1007/s11051-010-9900-y

[30] Huhtamäki T., Tian X., Korhonen J.T. et al.: Nature Protocols 2018, 13, 1521. https://doi.org/10.1038/s41596-018-0003-z

[31] Ragesh P., Ganesh V.A., Nair S.V. et al.: Journal of Materials Chemistry A 2014, 36, 14773. https://doi.org/10.1039/C4TA02542C

[32] Faille C., Jullien C., Fontaine F. et al.: Canadian Journal of Microbiology 2002, 8, 728. https://doi.org/10.1139/w02-063

[33] Van Berkel A.M., Bruno M.J., Bergman J.J.M.H. et al.: Endoscopy 2003, 35, 478. https://doi.org/10.1055/s-2003-39666

[34] Fu Y., Du H., Sun Ch.Q.: Thin Solid Films 2003, 424, 107. https://doi.org/10.1016/S0040-6090(02)00908-2

[35] Paldey S., Deevi S.C.: Material Science Engineering 2003, 342, 58. https://doi.org 10.1016/S0921-5093(02)00259-9 
[36] Gibeop N., Lee D.W., Prasad Ch.V. et al.: Advanced Composite Materials 2013, 6, 389. https://doi.org/10.1080/09243046.2013.843814

[37] Beníteza F., Martíneza E., Galán M. et al.: Surface and Coatings Technology 2000, 125, 383. https://doi.org/10.1016/S0257-8972(99)00581-2

[38] Dobrzański L.A., Śliwa A., Żukowska L.W. et al.: The Journal of Achievements in Materials and Manufacturing Engineering 2010, 42, 33.

[39] D'Avico L., Beltrami R., Lecis N. et al.: Coatings 2019, 9, 7. https://doi.org/10.3390/coatings9010007

[40] Prabhu S., Poulose E.K.: International Nano Letters 2012, 2, 32.

https://doi.org/10.1186/2228-5326-2-32
[41] Feng Q.L., Wu J., Chen G.Q. et al.: Journal of Biomedical Material Research 2000, 4, 662.

h t t p s : / / d o i.org / $10.1002 / 1097$ -4636(20001215)52:4<662::AID-JBM10>3.0.CO;2-3

[42] Woo K.J., Hye Ch.K., Ki W.K. et al: Applied and Environmental Biotechnology 2008, 7, 2171. https://doi.org/10.1128/AEM.02001-07

[43] Lemire J.A., Harrison J.J., Turner R.J.: Nature Reviews Microbiology 2013, 11, 371. https://doi.org/10.1038/nrmicro3028

[44] Russel A.D.: Journal of Antimicrobial Chemotherapy 2003, 52, 750.

https://doi.org/10.1093/jac/dkg422

Received 21 V 2019. 